\title{
8 \\ Meet the pagans: on the misuse of Beowulf in Andreas
}

\section{Richard North}

Christians they may be at the end of Andreas, but for most of this poem the Mermedonians are mad pagan cannibals. The devil has made them so, whilst their hopes of salvation improve only when they try to make St Matthew into one of their victims. According to this poem, an Old English verse adaptation in the Vercelli Book of a Latin version of a Greek apostolic romance, St Andrew converts the cannibals on the Lord's command after coming to their city to rescue his fellow apostle. Yet there is more to this Old English versification of a saint's legend than rescue mission, passion and mass conversion, for it also appears that the poet of Andreas, recasting Mermedonia as the inverse of Heorot and Andrew as Beowulf's ultimately stronger rival, subjects his pagans to a mock-epic ridicule, which his audience could not have enjoyed without knowing Beowulf. ${ }^{1}$

The immediate source of Andreas has not been found. It was probably a Latin

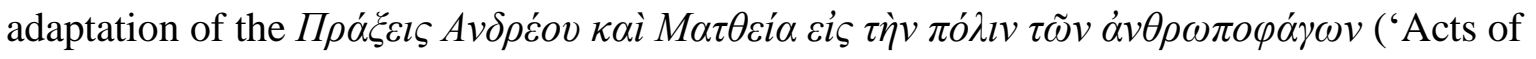
Andrew and Matthew in the City of the Cannibals'), which, though surviving in a manuscript from the end of the ninth century, has a text datable to $c .400$ with roots going back even further. ${ }^{2}$ All analogues differ, while even the $\Pi \rho \alpha \dot{\xi} \xi \varepsilon \varsigma$ (henceforth Praxeis) shows itself to be 
a later recension by omitting a name for the city or even mention of the bishop (Plato) whom Andrew consecrates for his Mermedonian converts towards the end. The 'Bonnet Fragment', from a manuscript of the eleventh century, provides a Latin text which is closest to the Greek, but which answers to no more than lines 843-954 of the Old English poem. The Codex Casanatensis, of the twelfth century, contains a full Latin adaptation, the Acta Andreae et Matthiae apud Anthropophagos, but this lies at a further remove from the Praxeis. ${ }^{3}$ Among other Latin adaptations yet further removed is a condensed poetic text in Codex Vaticanus 1274, of the mid-eleventh century, which is alone with Andreas in naming the bishop. ${ }^{4}$ Two Old English prose homilies with this story are fragmentary redactions of the same adaptation of a Latin text, which appears close to that in the Bonnet Fragment. One is a middle section of the narrative in the later tenth century collection of the Blickling Homilies, the other a fragment in the eleventh-century MS, Cambridge, Corpus Christi College $198 .^{5}$

The Old English Andreas, in its account of the transformation of its subject from reluctant apostle to fearless hero, is as much a saint's life as these analogues. ${ }^{6}$ However, it has also been noted that Andreas is composed with a unique and potentially comic wildness of expression. ${ }^{7}$ The Praxeis shows us that some such possibilities may have been available to the poet of Andreas in his source, as in the case of Andrew's dialogue with the ship's captain, Jesus in disguise, in his journey to Mermedonia in the first third of the story. ${ }^{8}$ Yet a wider comic tendency in Andreas is manifest in the poet's extravagant expressions, many of which appear to take Beowulf as their source. Indeed Andreas contains a higher number of verbal parallels with Beowulf than does any other Old English poem. ${ }^{9}$ Although these have been dismissed as oral-formulaic coincidences, ${ }^{10}$ enough textually comparative work has been done to redefine them as the poet's conscious or internalised loans. ${ }^{11}$ Here I shall discuss twelve examples. My first is when the poet calls Andrew a 'beorn beaduwe heard' ('warrior hard in battle') (line 982) as he marches on the jail in Mermedonia. These words for a miles 
Christi $^{12}$ may also recall the epithet 'beadwe heard', which describes Beowulf as he closes with Grendel's Mother, at Beowulf, line 1539. It is hard to treat the usage in Andreas as purely type-scene formulaic, for two reasons. One is that the Beowulf-poet's use of this epithet is visibly related to the Norse expression 'bøðvarr bjarki' ('battle-ready little bear'), which is the basis for the name of Beowulf's deep-fried heathen counterpart in the later Norse analogues. ${ }^{13}$ The other is the fact that there are no other examples of 'beadwe heard' in Old English literature. In Andreas it seems therefore likely that the poet calls Andrew 'beorn beaduwe heard' in order to make him a rival to Beowulf.

It is clear that the poet of Andreas borrows subversively from Beowulf from the moment he acclimatises the Mermedonians to heroic Scandinavia. Their story is that they arrest pilgrims and other passing backpackers in order to eat them after a fattening of thirty days. Notice of these pagans' meal-habits is soon followed in the poem by their unwitting parody of the Eucharist, in which 'næs pær hlafes wist' ('it was not loaf food there'), 'ne wæteres drync' ('nor drink of water') that they have for their use, but rather 'blod ond fel, / fira flæschoman feorrancumenra' ('blood and skin, flesh of men come from afar' on which they dine) (lines 21, 22, 23-24). The Mermedonian pagans perform an unwitting simulation of Christians, who can eat the body and drink the blood of Christ. In any other conversion narrative with a setting as far from England as a city by the Black Sea, they might look little worse than the Roman unbelievers in Cynewulf's Juliana and The Fates of the Apostles or the Jewish ones in his Elene. Yet the poet of Andreas is only too ready to mock his pagans, as a formula from Beowulf shows:

\section{Swelc wæs peaw hira,}

pæt hie æghwylcne ellðeodigra

dydan him to mose metepearfendum,

para pe pæt ealand utan sohte. (Andreas, lines 25-8) 
(Such was their custom,

that each man from a nation of foreigners

did they make, when needing food, into meat,

of those seeking that land by water from abroad.) $)^{14}$

This bare introductory half-line is all that is needed to bring the tragic Danes of Beowulf to mind. When Grendel invades Heorot, and when neither King Hrothgar nor his council can think of a solution, the Danes sink into despair and make offerings to the devil. The poet defends their actions as performed in ignorance of the true God:

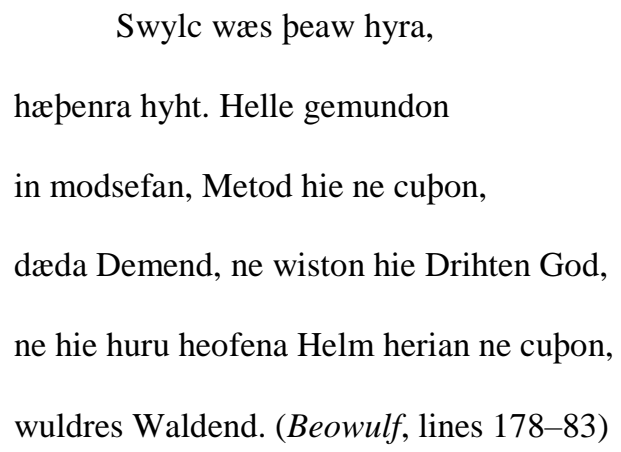

(Such was their custom,

hope of heathen men. They were mindful of hell

in their hearts, did not know the Measurer,

Judge of Deeds, nor were wise to the Lord God,

nor knew how to praise the Helm of heaven,

Ruler of Glory.)

The poet of Beowulf knows that the old Israelites were idolaters too (Exodus 32:1-6). His sympathy for these heathens as honorary Israelites may be seen in the objectivity with which he describes their rituals. Although the Danes pray to the devil, who will take their souls, they are as ignorant as they were two generations earlier, in lines 50-2, when they committed Scyld Scefing to the deep. Later, in defiance of his statement above, the poet of Beowulf allows his heathens to praise God most of the time. The monotheism into which Hrothgar's 
invocations have thus been morally translated is Israelite in all but name. To add to his salvage of heroic Scandinavian cousins, the poet leaves Hrothgar's name out of the idolatry about which he otherwise seems so open. In both passages, the funeral and the sacrifices, he takes the earliest care to introduce and alleviate the religious plight of his heathens.

The poet of Andreas makes a barbed reference to this compassion by deploying the half-line 'swelc wæs peaw hira' as early as line 25 of his work. A certain structural resemblance permits this, for both Beowulf and Andreas start with heroes setting off over high seas to rescue foreign nations from cannibal assaults. Without knowing it, Andrew even likens his own expedition to Beowulf's. When he says 'færeð famigheals fugole gelicost' ('with foamy neck she sails most like a bird') (line 497), of the ship he is in, he cites the Geat's 'flota famiheals fugle gelicost' ('vessel foam-necked most like a bird') (Beowulf, line 218). Yet there are also differences between Beowulf and Andreas sufficient to make one poem the mock of the other. The cannibals in Andreas are introduced as the host nation itself, and most other parallels are reflected in the manner in which the poet of Andreas represents them. The source that he versifies will have portrayed Mermedonians as provincial pagans living through a sub-Roman apocalypse. ${ }^{15}$ In the perforce heroic versification of this tale he turns these people into Scyldings. A city full of Grendels? Having entrapped St Matthew, who visited them earlier, the Mermedonians provide a potentially comic inversion of the Heorot scenario in which the visitor entraps the people.

Likewise, when Andrew is forced on his mission, he becomes the potential inverse of Beowulf. Having questioned the Lord's command to save Matthew in three days' time, then looking for his transport to Mermedonia by the shore the next morning, he cuts a poor figure alongside the headstrong Geat who leaves for Denmark against his uncle's wishes, having picked his own ship and crew. The modesty that a saint must have goes too far in this initial reluctance, and the exchange between Andrew on the shore and the sailors in the boat the 
next morning takes the comedy further. This is based on his failure to perceive that the ship's captain is his old friend Jesus in disguise. ${ }^{16}$ The Praxeis makes the dialogue short and careful. The captain is perfectly played and there may be comedy in the unworldly way in which

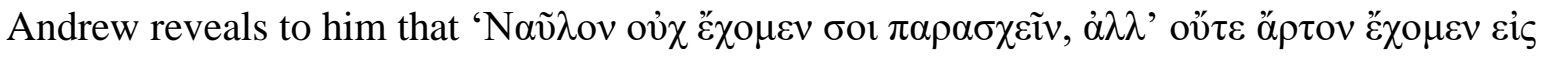

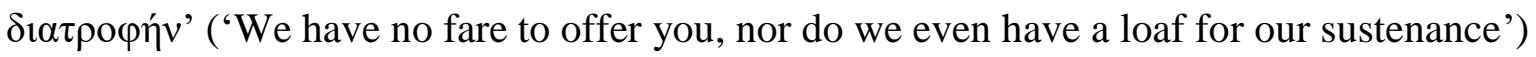
(ch. 6). ${ }^{17}$ But unworldliness is a saint's weapon: Andrew confirms his worth, for which the Lord is testing him, by saying that he is on a mission from God, and that if the captain cannot help, he and his men will find another boat. All this is before Andrew has boarded. The Casanatensis solemnises the discourse by letting Andrew and the others board before the Lord more prosaically tests Andrew by asking for the fare. Andrew answers, 'Crede mihi frater, quia nec aurum habeo, neque argentum, unde tibi naulum dare, set neque panem in sitarcis' ('Believe me brother, I have no gold, nor silver, with which to pay you my fare, nor even a loaf as part of my provisions') (ch. 6). ${ }^{18}$ The Latin captain responds with disbelief, rather than with irony, repeating the things that Andrew does not have in order to get a proper explanation. Andrew's ensuing mission statement defends his saintly poverty more elaborately than in the Greek, but with the same elements. The whole scene, as Wilcox has observed, is structured around the Eucharist, in that the Lord breaks bread with Andrew, which, since the disciples are too seasick to eat it, Andrew shares with Him. Andrew's assurance to the captain, that the Lord will offer him bread as recompense, captures the irony of the apostle's position. ${ }^{19}$

The Old English poetic version, which appears to follow a Latin source closer to the Praxeis, magnifies the hot saintly temper that is otherwise in the Casanatensis. Politely at first, hailing the captain from shore, Andrew asks for passage, 'beh ic pe beaga lyt, / sincweorðunga, syllan meahte' ('though few are the rings, treasures and adornments I could give you') (lines 271-2). Though Andrew adds that God will reward the captain, the message 
is lost on him. After citing the dangers of going to Mermedonia, the captain offers to ferry Andrew and the others to his city only when they have 'gafulrædenne agifen' ('yielded up payment of tribute'), 'sceattas gescrifene' ('coins as prescribed') (lines 296-7), that is, to the sailors' price. Andrew answers 'ofstlice' ('hastily') (line 299): with temper, to judge by his ensuing words. The poet calls him 'winepearfende' ('in need of friends') (line 300), as if Andrew will need them to pull him out of a brawl.

Andrew's answer is a satire of heroic expectations. Later he explains that the Lord taught him to live without gold and silver (lines 337-8), but to make his poverty clear to the merchant skipper now, he swaps the coins for an exaggerated image of treasure:

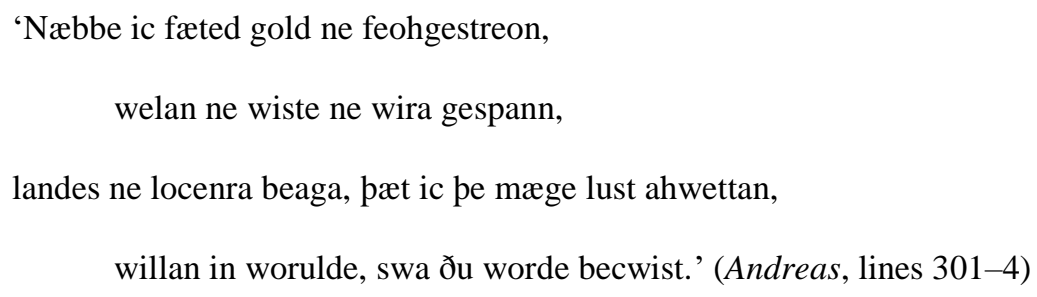

('I have no plated gold nor riches of treasure,

no wealth nor provisions nor fastening of wires,

no land nor linked rings, with which I can possibly arouse your desire,

such worldly pleasure as in words you reproach me for.')

In that the fabulous objects to which Andrew refers belong to kings, not captains, he makes a point about unreasonable expectations: Andrew is a missionary and the captain ought to know better.

Andrew makes his point still clearer with the hypermetric line 303. At first there seems to be a lack of clarity: the phrase 'landes ne locenra beaga' ('of land or linked rings') may be an 'objective genitive', produced by a poet who 'tries to write in the heroic style, but sometimes muddles it'. ${ }^{20}$ However, if this half-line is read as a quotation from Beowulf, the style is far from muddled. The phrase 'landes ond locenra beaga' occurs in the third of only 
three hypermetric passages in Beowulf. This is in the poet's dénouement concerning Hygelac, Beowulf's mother's brother and best friend. In the story, Beowulf is now dead and an unnamed Geatish messenger has returned home with the news. He sketches a reverse history of the wars that the Geats have fought with their neighbours: first with the Franks, who killed Hygelac when he raided their territory; then with old king Ongentheow of the Swedes, who killed Hæthcyn in the battle of Ravenswood, threatened death to the Geatish survivors all night long, only to withdraw when Hygelac, the younger brother, marched in to save them all in the morning. Hygelac routs the Swedes and sends his champions Wulf and Eofor after King Ongentheow. When the kings falls, after a ferocious fight with these brothers, Hygelac loots the Swedish kingdom and returns home in triumph. Then, with dire consequences for the stability of his own country, he rewards the champions with riches beyond the dreams of avarice:

\author{
'geald pone guðræs Geata dryhten, \\ Hreðles eafora, pa he to ham becom, \\ Iofore ond Wulfe mid ofermaðmum, \\ sealde hiora gehwæðrum hund pusenda \\ landes ond locenra beaga (ne ðorfte him ða lean oðwitan \\ mon on middangearde syððan hie ða mærða geslogon), \\ ond ða Iofore forgeaf angan dohtor, \\ hamweorðunge, hyldo to wedde.' (Beowulf, lines 2991-8)
}

('The lord of Geats, Hrethel's offspring, when he came

to his home-seat, paid Eofor and Wulf

for that war-charge with an excess of treasure,

gave each of them one hundred and twenty thousand

of land and linked rings (nor need any man in the middle world begrudge 
them that reward, since they had won those glories by fighting for them)

and then he gave Eofor his only daughter

as ennobler of his estate, the pledge of his loyalty.')

If this hypermetric sequence means anything in Beowulf, and of course its metrical distinctness and even authenticity have been questioned, ${ }^{21}$ it is that the end of Hygelac's career is implicit in its beginning. Hygelac's prodigal generosity will become a habit to be replenished by ever riskier ventures until the excess of it leads him and all but one of his retinue to their doom on the Rhine. This is a highly political image of disaster, one far from the apparently mundane ship's captain to shore situation that we have before us in Andreas. However, it may be argued that the half-line in Beowulf is the source for its near-double in Andreas. By unwittingly citing a negative version of the Geatish messenger's 120,000 units of land and linked rings, Andrew uses Beowulf to give him the catchphrase for a spendthrift king.

The poet's own view of treasure emerges in the course of a fifth apparent borrowing from Beowulf. Describing Andrew's ship as filled with it as Scyld Scefing's, he makes it nonetheless clear that he is praising her complement, Andrew and his disciples as well as the angels and heavenly captain:

Æfre ic ne hyrde

pon cymlicor ceol gehladenne

heahgestreonum. (Andreas, lines 360-2)

\footnotetext{
(Never did I hear

of any keel the comelier laden

with high treasures.)
}

The poet of Beowulf uses similar language to describe Scyld's funeral ship before she is shoved on the deep, destination unknown: 
ne hyrde ic cymlicor ceol gegyrwan

hildewæpnum ond heaðowædum

billum ond byrnum. (Beowulf, lines 38-40)

(Nor did I hear of a comelier keel made ready

with war-weapons and battle garments,

with axes and coats of mail.)

The social importance to the Beowulf-poet of this treasure is clear; a few lines later he calls it 'peodgestreonum' ('royal treasures') (line 44). Yet from the evident re-use of the crucial words in Andreas it appears that the later poet repeats Beowulf's 'never-yet-heard' topos in order to portray Andrew's ship as even better than Scyld's. The real treasure is of the spirit, and Andrew's scorn for money is the correct attitude to have.

A sixth borrowing from Beowulf turns Andrew's zeal into artless condescension. Just when we think, through Andrew's sustained praise of God in lines 540-8, that he has grasped the identity of the young captain who asks him all the questions, Andrew reveals no understanding at all:

'Huru is gesyne, sawla nergend,

pæt ðu pissum hysse hold gewurde

ond hine geongne geofum wyrðodest,

wison gewitte ond wordcwidum!

Ic æt efenealdum æfre ne mette

on modsefan maran snyttro.' (Andreas, lines 549-54)

('Indeed it can be seen, O Saviour of Souls, what favour you have shown to this boy, with what gifts honoured him young as he is, with what wise wit and eloquence! 
In a man of his age I have never met

greater cleverness of mind.')

This parting flourish is lacking in the analogues, whose speech ends with a paean to the Almighty. Beowulf, however, provides a parallel, even if not in the form of a quotation, for Hrothgar condescends to Beowulf similarly just before the hero takes his leave. This foreign champion has helpfully indicated some trouble for Denmark in the near future. There may be an invasion for which he promises to bring a forest of Uncle Hygelac's spears (lines 182635): this turns out to be Ingeld's revenge raid on Heorot. Possibly, in his offer to foster Hrethric, there may be a threat to Hrothgar's sons (lines 1836-9): this turns out to be true as well, coming from Hrothulf, their next king and cousin. ${ }^{22}$ Wise as he is, Hrothgar fails to understand any of it:

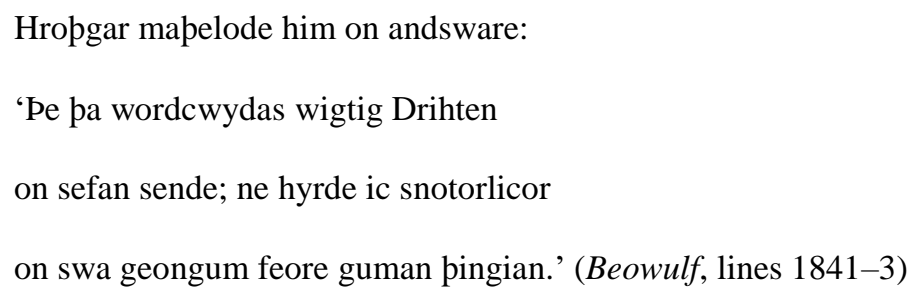

(Hrothgar then spoke to him in answer:

'These words you have uttered the wise Lord sent to your heart; nor have I heard a man at such young stage of life intercede more cleverly.')

The difference lies not between Andrew and Hrothgar, who are both beyond middle age, but between their interlocutors. As the young ship's captain is the Lord in disguise, Andrew's mistake is worse than Hrothgar's.

This is brought home to him the next morning. After angels carry them all to a place of rest outside the walls of Mermedonia, Andrew's disciples reveal a heavenly vision from which he has been pointedly excluded, whereupon the Lord reappears as a little boy, rebuking 
Andrew for his original doubts. The agents of humiliation become younger each time.

However, the result is positive in that after this nadir Andrew begins to harden to the task. Leaving his disciples behind, just like Beowulf, though unlike him invisible, he earns the hero's epithet, 'beorn beaduwe heard' ('a warrior hard in battle') as he moves on the Mermedonian jail in line 982. This use marks a turning point, for the humiliations inspire Andrew's courage to equal Beowulf's.

A seventh example of the poet's use of Beowulf may be seen in the hero's entry into the jail. As soon as he reaches this place in town, divine intervention ensures that all seven guards drop dead. The Praxeis and the Casanatensis both let Andrew into the jail through a

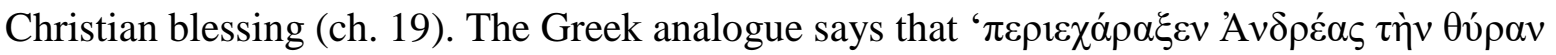

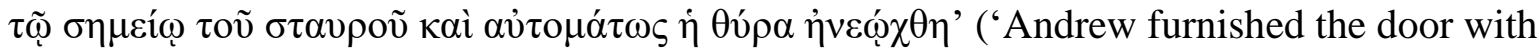
the sign of the cross, and the door opened of its own accord'); the Latin analogue says of Andrew, with a little more detail, that 'extendens dexteram suam ad carcerem, fecit signum sancte crucis' ('and stretching out his right hand towards the jail, he made the sign of the holy cross'), whereupon the guards drop and 'ianua vero carceris statim aperta est eis, et ferrum ipsius ianue dissolutum est' ('indeed the door of the jail was at once opened for them, and the same door's iron was melted'), as are the chains on the prisoners. ${ }^{23}$ Andreas follows the sequence of events in the Praxeis, while emphasising the 'dextera' ('right hand') of the Casanatensis. Just as in the analogues, Andrew 'se halga' ('the saint') (line 996) prays to the Father within his breast, praising 'Godes dryhtendom' ('God's lordship') (line 999). In the following, whether the manuscript reading 'gastes' is for the Holy 'Spirit' ('gāst') and the Lord accomplishes what Grendel does with His hands, or this is for Andrew as the holy 'guest' ('găst' for 'gæst') in Mermedonia, Andrew is recast as a cannibal:

Duru sona onarn

purh handhrine haliges gastes, 
ond pær in eode, elnes gemyndig,

hæle hildedeor. Hæðene swæfon,

dreore druncne, deaðwang rudon. (Andreas, lines 999-1003)

(At once the door rushed open

with a touch from the hand of the holy guest,

and inside, inspired by valour, marched in

a man daring in battle. Heathens were sleeping,

drunk with blood, had reddened the place of death.)

The dead outside are thus glimpsed as if sleeping inside. As may be seen below, the effect of this figure is to remind us of a scene in Beowulf. The hand-touch points to Grendel's forced entry. First there is the long-awaited approach of this wretched 'rinc' ('man') 'dreamum bedæled' ('of happiness deprived') (lines 720-1). Then the splintering wood:

Duru sona onarn,

fyrbendum fæst, sypðan he hire folmum æthran;

onbræd pa bealohydig, ða he gebolgen wæs,

recedes mupan. Rape æfter pon

on fagne flor feond treddode,

eode yrremod. Him of eagum stod

ligge gelicost leoht unfæger.

Geseah he in recede rinca manige

swefan sibbegedriht samod ætgædere

magorinca heap. (Beowulf, lines 721-30)

(At once the door rushed open,

made firm with fired bonds, when his hands touched it;

with evil purpose he swung it open, now he was enraged,

the building's mouth. Swiftly after that 
did the fiend tread in on stained floor,

walk in wrathful of mind. From his eyes appeared,

most like a flame, a light of no beauty.

Saw there in the building many warriors,

a kindred comitatus sleeping together,

a band of young men.)

At first it might seem hard to establish why the poet of Andreas alludes to Grendel's entry in this way, just when his hero is ready to snatch Matthew and the other prisoners from a fate worse than death. Yet, as Hamilton says, he 'reverses what we may think of as the received point of view'. ${ }^{24}$ The effect is to ironise expectations of disaster in an audience habituated to Beowulf. Hearing the door give way, Matthew and the others expect a cannibal but get Andrew instead. The hagiographic effect is Andrew's warm reunion with Matthew under the eyes of Christ (lines 1004-19), where the statement 'syb wæs gemæne / bam pam gebroðrum' ('goodwill was shared between both brethren') (lines 1013-14) emphasises the faith community of the apostles and its ascendancy over all tribal kindreds such as the 'sibbegedriht' ('kindred comitatus') sleeping in Heorot (Beowulf, line 729). This spiritual uplift is the greater for coming after Andrew's Grendel-like entry into the jail.

Not long after Andrew has dropped the guards and released all the prisoners, the townsfolk go mad with hunger, and not for the first time the English poet puts a strain on the story. Using Beowulf to sharpen his attack on Mermedonian pagans, in the eighth example to be discussed here, he illustrates their cannibalism in action, then presents this as a parody of the Eucharist. As in the Casanatensis (by implication at the end of ch. 24), the poet lets his Mermedonians eat all seven dead guards:

Durupegnum wearð

in ane tid eallum ætsomne purh heard gelac hild<e>bedd styred. (Andreas, lines 1090-2) 
(For the door-thanes,

in one hour, for all of them together,

in harsh play was their war-bed disturbed.)

The Praxeis and Casanatensis give a more detailed preliminary in which the Mermedonians haul the dead guards to a trough (' $\lambda \eta v o ́ \varsigma$ ') or tank ('lacus') in the square, one with runnels for the blood, and next to an oven (ch. 22). This appears to be the source of the poet's 'hild<e>bedd' (line 1092) at the centre of the cannibal feast.

The poet's effect by his invocation of 'feormian' ('to take dining rights') on this line is to present the Mermedonians as insane hypostases of Grendel, who 'sona hæfde . . . eal gefeormod' ('had soon fed up on all') of Hondscio's lifeless body in Beowulf, lines 743-4. In the Praxeis and Casanatensis, the locals are mad, but if there is a contradiction, still bureaucratic in the way they attend to the details. The devil has done well, ingraining the cannibal state so deeply in these pagans that they see no alternative, once their meals have escaped, to finding substitutes from the dead guards, or from among themselves. In the midst of his cannibal fantasia the English poet points up an irony in his likely source. ${ }^{25}$ Although the text is corrupted, it is possible to see that he refines the eucharistic irony in the scene that follows the feast. ${ }^{26}$

Once the mob have devoured the dead guards, we have, in lines 1108-12, what might be called an anti-Eucharist: a human father sacrificing his son to save his own life, as well as to give the Mermedonians a continuation of theirs. The analogues, just after the Mermedonians fail to eat their prisoners, give an extended scene in which the Mermedonian rulers plan to eat seven fresh victims from among their own people that day and seven more daily from then on. Clearly the madness of the city is reaching its climax. When the council assigns a group of old people to the shambles, which will provide the next meal, one of them gets out of it by offering his son and then his daughter in his place. The English poet simplifies the scene, adducing some divination, which singles one old man out in particular, 
rather than seven to stand in for the guards. Moreover, this man offers only a son. The logistics of supply and demand are dismissed in Andreas for the sake of this one striking gesture:

Đa se tan gehwearf efne ofer ænne ealdgesipa, se wæs uðweota eorla dugoðe, heriges on ore. Hraðe siððan wearð fetorwrasnum fæst, feores orwena. (Andreas, lines 1103-7)

(Then the twig passed right over one particular old campaigner who was the philosopher of a troop of nobles in the host's front line. Quickly thereafter was he fastened in tight bonds, no hope for living more.)

This man is not only old, he stands for such authority within his society as the Mermedonians

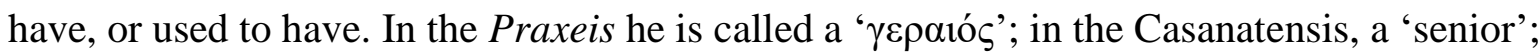
both meaning 'old man'. ${ }^{27}$ In the poem, however, his age comes ready with a socially endorsed wisdom. And what wisdom it is. The term 'uðwita' connotes a man of philosophy, science or learning. ${ }^{28}$ Cynewulf uses 'uðweotan' ('scholars') in Elene for the pharisees who 'æht bisæton, / on sefan sohton hu hie sunu meotudes / ahengon ('sat in council, sought answers in their minds to how they might hang up the Measurer's Son') (lines 473-5). The bad father in Andreas is more of their presumed kind, but the son will be his own:

Cleopode pa collenferhð cearegan reorde, cwæð he his sylfes sunu syllan wolde on æhtgeweald, eaforan geon[g]ne, lifes to lisse; hie ða lac hraðe pegon to pance. (Andreas, lines 1108-12) 
(Cried then the stout-hearted with grieving voice,

said that he would give up his own son

into their power, his young heir, in exchange

for enjoying life; they on that offer quickly

dined with thanks.)

This scene is refocused so as to echo the Father's sacrifice of His Son. The poet presents the impending feast as a pagan Eucharist, one without transubstantiation or 'lif', which is eternal. Possibly this poet is reflecting, as Boenig believes, a mid-ninth-century Corbie controversy over whether to endorse a respectively figural or literal interpretation of Christ's eucharistic flesh and blood. ${ }^{29}$ Yet his immediate aim appears to be a parody of the old man and his society. It is to keep his and their lives going in this world that the 'uðweota' lets the Mermedonian mob participate in the body of his son. Calling him wise and brave, in the voice of their heroic culture, as the poet does here, turns the pagans into fools.

With this mockery the poet of Andreas strikes at the moral underbelly of Beowulf. Rendering the Mermedonian trough or tank into a 'hild<e>bedd' ('bed of war'), perhaps a war-grave (line 1092), he may trigger a reminiscence of a speech in which old King Beowulf tells his men how Herebeald, King Hrethel's eldest son, died by mistake at the hands of his brother Hæthcyn:

'Wæs pam yldestan ungedefelice

mæges dædum morporbed stred.' (Andreas, lines 2435-6)

('Unfittingly for the eldest through kinsman's actions was a bed of death dispensed.') 
These lines introduce the tragedy of Hrethel, which Beowulf relates to the platoon accompanying him to the Dragon (lines 2426-2519). Beowulf recalls his childhood, that King Hrethel, his grandfather, took him in at the age of seven. Hrethel kept him, enriched him, 'sibbe gemunde' ('was mindful of kinship') (line 2431). Beowulf recalls that he was no less dear to Hrethel than the latter's own sons, Herebeald and Hæthcyn and Hygelac. When the eldest died, killed by Hæthcyn's misdirected arrow (or spear), there was no compensation, or vengeance, and much grief. Hrethel mourned, says the aged Beowulf to his men, with as little point as a churl mourning for his hanged and thus unrecompensed son (lines 2450-3). Just so did the Geatish guardian carry the 'heortan sorge weallinde' ('welling heart's sorrow') (lines 2463-4), finally dying of it:

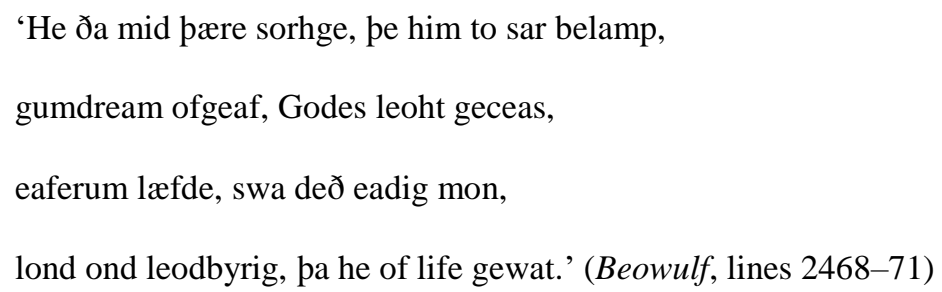

Both men, the churl and Hrethel, compose elegies with which to purge themselves of grief, but the old king dies of his. Beowulf's simile is complicated by its allusive depth, for it plays the king off against a type. The 'gomel ceorl' ('old churl') with the hanged son provides not only a comparison for Hrethel, but also an apparent stylisation of his dilemma within the mythology of Hrethel's homeland: Icelandic sources tell us that Hǫðr slays his brother Baldr, son of 'karl' ('churl') Óðinn. ${ }^{30}$ The (Odinic) vengeance on one son for the death of another is a course that the father could follow, since he has no love for Hæthcyn (Beowulf, lines 2464- 
7). However, the old king refrains, dying of grief instead and thereby emulating a Christian martyrdom even while living in ignorance of Christ. With the half-line 'Godes leoht geceas', the poet of Beowulf indicates that a seat in heaven may reward the conduct and intuition of this grieving father. This tragic tale, into which the phrase 'morporbed stred' ('bed of violent death dispensed') (line 2436) for Herebeald leads us, counts as the most pathetic idealisation of heathens in Beowulf..$^{31}$ As an evocation of pathos for the pre-Christian condition, it is also the Beowulf-poet's big occasion for nostalgia. The poet of Andreas seems determined to have a go at him for this, echoing his opening in 'hild<e>bedd styred', then recasting Hrethel as a self-centred infanticide.

Having saved the son who was to be eaten instead of his father, Andrew submits to arrest. The Mermedonian townsfolk spend the following three days in an orgy of torturing, flogging and dragging the saint in and out of his cell and around the city. Andrew's blood flows in gouts and his flesh scatters through the streets of this heathen city like a premonition of the wine and host that the cannibals will come to celebrate. His resolve weakens so far that he rebukes Jesus for not being exact about the punishment he was led to expect. Christ suffered within one day, Andrew for three. Yet the legend makes clear what the torture is for. When the Lord responds, restoring Andrew's broken body to a state better than new, our man is transformed into the full apostle, a spiritual warrior with the power of miracles. This is an improvement on the powers of the half-monstrous heathen Beowulf, with whom the poet's expressions have compared Andrew unfavourably for more than half the poem.

The flood-scene that follows in Andreas confirms the saint's new powers in the poem's greatest set-piece, one that alludes to Beowulf in two more ways (our ninth and tenth examples). In the analogues of Andreas, St Andrew starts off the punishment and conversion of his cannibal captors by ordering a statue to discharge a salt-water flood through its mouth. Typologically this scene is a simulation of baptism. ${ }^{32}$ The waters rise higher, eating the 
cannibals who would have eaten Matthew. A wall of flame around the city, laid on by an angel (in the Praxeis, Archangel Michael) at Andrew's request, makes sure that the Mermedonians stay on in their city to drown. In Andreas the stone is a pillar, not a statue, but wastes not a moment in obeying Andrew's command. A stream wells up in the dawn, flows out and floods the city, increasing in size. Our poet, never able to resist a metaphor, ${ }^{33}$ turns the flood into a feast as only heroic poetry can present one: no food but no lack of drink. All this he encapsulates in his unique opening word:

\section{Meoduscerwen wearð}

æfter symbeldæge, slæpe tobrugdon

searuhæb $<\mathrm{b}>\mathrm{ende}$. Sund grunde onfeng,

deope gedrefed. Duguð wearð afyrhted

purh pæs flodes fær. Fæge swulton,

geonge on geofene guðræs fornam

purh sealtes swe $<1>$ g; pæt wæs sorgbrypen,

biter beorpegu! Byrlas ne gældon,

ombehtpegnas. Pær wæs ælcum genog

fram dæges orde drync sona gearu. (Andreas, lines 1526-35)

(It was a serving of mead

after the feast-day, men who kept weapons

woke from their sleep. Sea enfolded ground, stirred from the depths. The company took fright

at this flood's assault. Doomed, they died, young men in ocean snatched by war-charge of salt swallow; that was a brewing of sorrow, a bitter beer-tasting! Cup-bearers did not dally, servants and thanes. There was drink enough at once ready for all from the start of day.) 
From the sweetness of mead, this drink turns bitter, and the 'meoduscerwen' figure has been imagined as 'poculum mortis'. ${ }^{34}$ It might be, but 'the cup of death' still forms part of the cultural background rather than informs the passage. The immediate image is different, that of a wild party going wrong, a self-inflicted disaster, the poet's own metaphor for heathendom in general. ${ }^{35}$

The 'meoduscerwen' hapax in this passage has been read without difficulty through the elements OE 'meodu' ('mead') and 'scierwan' ('to dispense'); any notion that the latter word contains the opposite meaning, 'deprive', is laid to rest by the deluge of the context. However, 'meoduscerwen' also recalls the notorious word 'ealuscerwen' in Beowulf, likewise a hapax. Despite the likelier direction of poetic loans, most critics read 'ealuscerwen', which is even harder to interpret, as a word of the same category as the compound in Andreas. ${ }^{36}$ In Beowulf, the word 'ealuscerwen' occurs at the height of Beowulf's fight against Grendel, just when we see that the monster is about to lose. Beowulf has waited in the shadows, allowing Grendel to eat the unfortunate Hondscio so as to lower his guard. Once in the grip, Grendel thinks of fleeing: at this moment Beowulf's victory over the cannibal is achieved. The poet of Beowulf uses 'ealuscerwen' to announce this. Some critics state that the latter word is a metaphor for an attack as an overheavy drinking bout, but they ignore this scene's tipping of the balance of power. ${ }^{37}$ The poet of Beowulf starts off by saying that Grendel's was a 'geocor sið' ('melancholy mission') (line 765). The hall of Heorot resounded:

Denum eallum wearð, ceasterbuendum, cenra gehwylcum, eorlum ealuscerwen. Yrre wæron begen, repe renweardas. Reced hlynsode. (Beowulf, lines 765-70)

(For all the Danes, for fortress-dwellers, for each keen man, for noblemen, there happened 
a prescription of good fortune. Both were wrathful,

fierce the house-janitors. The building boomed.)

Both 'meoduscerwen' and 'ealuscwerwen' are governed by 'wearð', the preterite of 'weorðan' ('become, happen'). Elsewhere I have followed a theory (of Ursula Dronke; personal commuication) that the ealu-prefix to the Beowulf compound denotes 'good fortune' rather than 'ale', its homophone; that 'ealu', connoting 'prosperity', is found inscribed as 'alu' in runes on fourth-century bracteates, on a sixth-century pot lid in Spong Hill, and in Old Scandinavian on the Eggjum stone in eighth-century Norway; ${ }^{38}$ and that the scierwenbase here connotes a carved dispensation of good fortune. ${ }^{39}$ That image is in the three Norns in Voluspá ('the sibyl's prophecy') (c. 1000), of whom Urðr ('what has happened') and Verðandi ('what is happening') are named as two, and Skuld ('what must happen'), as the third. With the half-line 'skáru á skíði' ('they cut marks on wood') in stanza 20/7, the Norns are shown to carve men's fates on slips of wood:

pær lǫg lǫgðu, pær líf kuru alda bǫrnum, ørlǫg seggja. (Voluspá, 20/9-12) ${ }^{40}$

(They laid down laws, they chose lives for mankind's children, the destinies of men.)

Some notion of carving a manifest destiny appears in the word 'ealuscerwen' in the scene in Beowulf. With the word 'ealu' denoting 'good fortune', with 'scerwen' being related to 'scieran' ('to cut') and with four dative phrases embodying the recipients, our reading of this compound is best figured through the above Icelandic image of Norns inscribing symbols for men. Hereby the poet of Beowulf appears to mark the beginning of victory over Heorot's twelve-year predator.

In Andreas, in mocking contrast, the compound meoduscerwen marks the beginning of defeat for Mermedonia. Whereas the poet of Beowulf, if ealuscerwen means 'prescription' 
or 'dispensation of good fortune' (Beowulf, line 769), describes people from the Germanic past respectfully with a metaphor from the same pre-Christian time, the poet of Andreas appears to treat this expression as ripe for mockery: in his day, ealuscerwen may have looked like antique nonsense. His purpose, being determined by the story in his source on St Andrew, is so different from that of Beowulf that his word-formation on the basis of a pun on the homophone in ealu-scerwen, as 'a dispensation of ale', looks like a wilful misreading. This is despite the fact that, in its context, the destruction of cannibals with a generous serving of sea-water, meoduscerwen is no less dramatic.

In what may be counted as a tenth use of Beowulf, the poet mocks Heorot's deliverance further by letting his Mermedonians sing. As the flood-waters rise higher, the

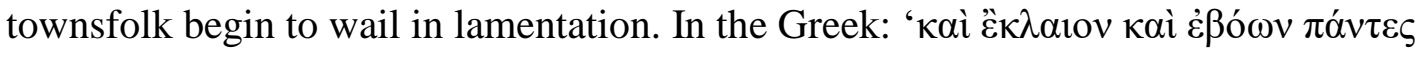

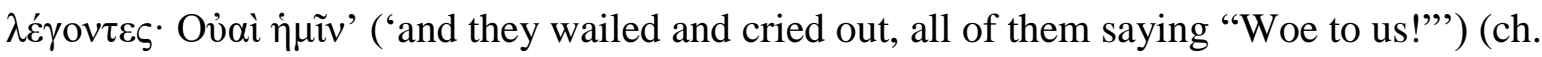
30 ); in the Casanatensis, 'exclamaverunt omnes in impetu, et fletu magno dicentes, ve nobis de ista omnia que supervenerunt nos' ('they cried out, all of them, in a convulsion, and with great weeping, they said "Woe to us for all those things which have come upon us!"”) (ch. 30). ${ }^{41}$ Admitting the error of their ways, they earn the mercy that Andrew provides. The poet of Andreas gives an extra edge to this lamentation, for unlike his likely source, he turns the cannibal wail into a composition of songs:

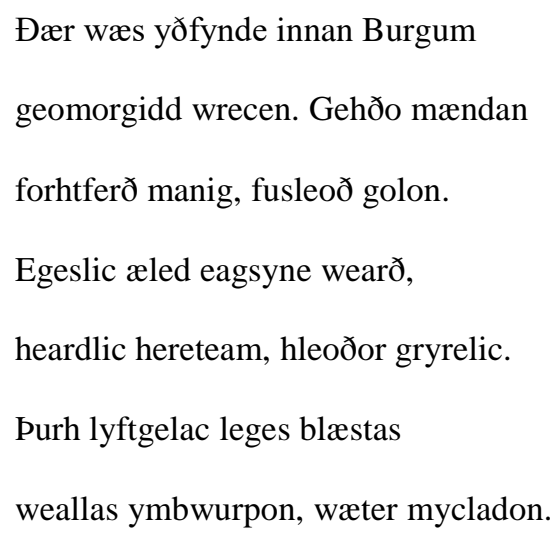


Pær wæs wop wera wide gehyred,

earmlic ylda gedræg. (Andreas, lines 1547-55)

(Easy was it to find there inside the town

a performance of the blues. Bewailed their grief

many fear-stricken men, chanted eager litanies.

Terrifying fire became clear to the eye,

cruel devastation, voices raised in horror.

With airborne commotion did blasts of flame

envelop the walls, the waters grew higher.

Weeping of men there was widely heard,

piteous the mob of men.)

As the Mermedonians, still pagan at this stage, are not human, the poet lets the humour run riot. There is more kindness in the way Grendel's singing is described when he begins to lose the battle in Heorot:

Sweg up astag

niwe geneahhe. Norð-Denum stod

atelic egesa, anra gehwylcum

para be of wealle wop gehyrdon,

gryreleoð galan Godes ondsacan,

sigeleasne sang, sar wanigean

helle hæfton. Heold hine fæste

se pe manna wæs mægene strengest

on pam dæge pysses lifes. (Andreas, lines 782-90)

(A melody arose,

a new one, constantly. Danes in Norway were struck

with a terrible fear, any one of them

who heard this weeping from his sea-wall, 
a litany of horror chanted by God's adversary,

a song with no victory, an anguish keened

by hell's captive. He held him fast

who was physically the strongest

of all men in that day of this life.)

In this passage the poet of Andreas appears to recall Grendel, God's adversary, 'gryreleoð galan' ('chanting a litany of horror') (Beowulf, line 786), particularly with 'fusleoð golon’ 'chanted eager litanies' (line 1549), the natural outcome of festivity which begins with the word 'meoduscerwen' ('serving of mead') (Andreas, line 1526).

Once the survivors of this unofficial baptism have asked for a real one, Andrew bids the flood subside, rejoices at the change of heart and, with a prayer to Jesus, brings all but fourteen drowned pagans back to life (Andreas, lines 1613-24). He orders the building of a church and consecrates a bishop named Platan ('Plato') (line 1652). ${ }^{42}$ The Mermedonians are transformed into Christians, their city into the Eucharist, all on a massive scale. Mermedonia is now a 'winburg' ('wine-town') in the narrator's and the Lord's words (lines 1637 and 1672). The poet also portrays Mermedonia, when Andrew wants to leave it with the job half done, as a 'goldburg' ('gold-town'), with 'secga seledream ond sincgestreon' ('hall-joys of men and treasure hoards'), the sleek complacent 'beorht beagselu' ('bright ring-palaces'), which he cannot bear to stay in (lines 1655-7). The transformation is that of the city itself. In the devil's infiltration earlier, Mermedonia looked like a set for Dawn of the Dead. But now the embarrassing past has become a surreal memory and the locals regret Andrew's decision to leave. Why, becomes obvious when the Lord forces Andrew to return: the devil is still there. The poet's view of pagans, which resembles knowledge more than fantasy, is that a truly efficacious conversion requires more than one attempt.

My eleventh and twelfth claims of Beowulfian allusion come in this poet's selfinterruption before his flooding set-piece towards the end: 
[XIV] Hwæt, ic hwile nu haliges lare,

leoðgiddinga, lof pæs pe worhte, wordum wemde, wyrd undyrne ofer min gemet. Mycel is to secganne, langsum leornung, pæt he in life adreag,

eall æfter orde. Pæt scell æglæwra mann on moldan ponne ic me tælige findan on ferðe, pæt fram fruman cunne eall pa earfeðo pe he mid elne adreah, grimra guða. Hwæðre git sceolon lytlum sticcum leoðworda dæl furður reccan.

Pæt is fyrnsægen, hu he weorna feala wita geðolode, heardra hilda, in pære hæðenan byrig. (Beowulf, lines 1478-91)

XIV (Listen, for a while now I have been pleading words in verse ballad so as to teach what glories the saint performed, a history which is, when revealed, beyond my capacity. A big task it is, a work of time-consuming study, to say all he suffered in life from the start. Wiser in the law than I is the earthly man, by my reckoning, who shall find in his spirit the means of knowing from the beginning every hardship that the man courageously suffered in that fierce fighting. And yet the narration of a few lyrics more in little snatches on this theme must still be made.It is an epic of ancient times, the great number of torments he endured, what harsh assaults in that heathen town.) 
This rakishly self-deprecating digression is unmatched in the analogues and so unlikely to be based on the apocryphal source, which is marked as 'wyrd undyrne' ('a history revealed') (line 1490), apparently in allusion to 'wurd undyrne' in (only) Cynewulf's Fates of the Apostles (line 42). Moreover, the half-line 'ofer min gemet' ('beyond my powers') is elsewhere attested only in Beowulf (line 2879), where young Wiglaf berates himself for failing to help Beowulf survive the Dragon. The function of the whole intermezzo, as Fred Biggs suggests, may be to dissociate Andrew's passion from the happy ending 300 lines later. ${ }^{43}$ Yet if we look in Beowulf for the words to which the fyrnsagen-claim of genre may refer, we see the Andreas-poet taking a stance on epic form. This he portrays as overblown but inevitable. Beowulf gives an unnamed Danish noble celebrating the hero on their ride back from the mere:

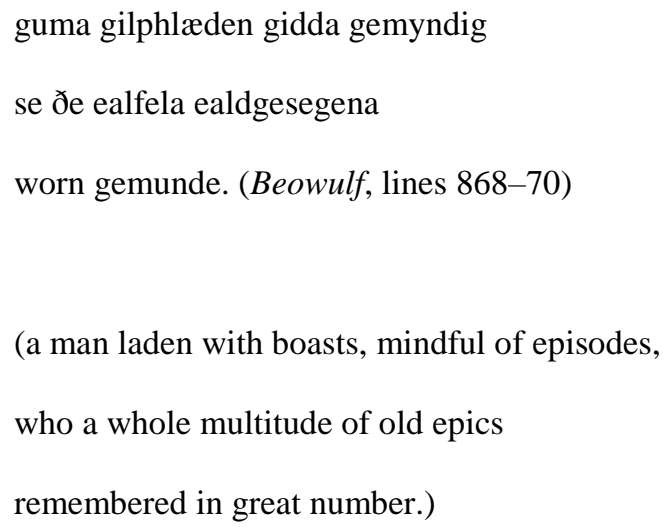

In Beowulf this king's thegn does in retrospect what his monastic imitator is about to try in Andreas. One man refers to 'ealdgesegena', the other to 'fyrnsægen', both to hail victory against the cannibal. Yet the poet of Andreas more modestly calls his own work 'leoðgiddinga' ('a verse ballad') (line 1479), an expression that occurs elsewhere only in Fates of the Apostles (line 97). With this term he appears to allude to Cynewulf as his model for the versified saint's life, whereas with his quotation from Beowulf he mocks epic as a dragon and himself as another Wiglaf attempting to slay it, his mentor almost dead. 
To sum up, I suggest that the poet of Andreas made fun of the Mermedonians by redrawing them as Scyldings now blended with Grendel their oppressor. There was surely a contrast between the legendary Danes of Beowulf and the living examples who looted English monasteries in the ninth and tenth centuries. Whether some communal knowledge of that experience is the cause of the Andreas-poet's quixotic style is a question I explore elsewhere. ${ }^{44}$ Here it will be enough to claim that the man sharpens his saint's life with a Cervantesque parody of Beowulf. My deduction is that he and his audience knew Beowulf as a classic and yet begged to differ on its vision of heathens as tragic. To this end the Andreaspoet makes Andrew a stronger hero than Beowulf, and through his pagans he mocks a cult of that great poem.

\section{Notes}

1 K. R. Brooks (ed.), Andreas and the Fates of the Apostles (Oxford: Oxford University Press, 1961); B. Mitchell and F. C. Robinson (eds), Beowulf: An Edition with Relevant Shorter Texts (Oxford: Blackwell, 1998).

2 C. Tischendorf (ed.), Acta Apostolorum Apocrypha, rev. R. A. Lipsius and M. Bonnet, 2 vols (Hildesheim: Olms, 1959), II.1, pp. 65-116; my translation is based on D. R. MacDonald, in J. K. Elliott (ed.), The Apocryphal New Testament: A Collection of Apocryphal Christian Literature in an English Translation (Oxford: Oxford University Press, 1993), pp. 287-99. Cf. R. Boenig, The Acts of Andrew in the Country of the Cannibals: Translations from Greek, Latin, and Old English, Garland Library of Medieval Literature, 70.B (New York and London: Garland, 1991), pp. ii, $\mathrm{v}-\mathrm{ix}$. 
3 F. Blatt (ed.), Die lateinischen Bearbeitungen der Acta Andreae et Matthiae apud Anthropophagos, Beihefte zur Zeitschrift für neutestamentliche Wissenschaften, 12 (Giessen: Topelmann, 1930); M. J. B. Allen and D. G. Calder (trans.), Sources and Analogues of Old English Poetry: The Major Latin Texts in Translation (Cambridge: D. S. Brewer, 1976), pp. 14-34.

4 F. M. Biggs (ed.), Sources of Anglo-Saxon Literary Culture: The Apocrypha, Instrumenta Anglistica Mediaevalia, 1 (Kalamazoo, MI: Medieval Institute Publications, Western Michigan University, 2007), pp. 40-1.

5 R. J. Kelly (ed. and trans.), The Blickling Homilies (London and New York: Continuum, 2003), pp. 158-63 and 195. MS CCCC 198 (fols 38 recto to 394 verso) is edited in The Blickling Homilies of the Tenth Century, ed. R. Morris, EETS, OS, 58, 63, 73 (London: Oxford University Press, 1874, 1876, 1880), reprinted as one volume (Oxford: Oxford University Press, 1967), pp. 228-9 and 236-49.

6 I. Herbison, 'Generic adaptation in Andreas', in J. Roberts and J. Nelson (eds), Essays on Anglo-Saxon and Related Themes in Memory of Lynne Grundy (London: King's College London Centre for Late Antique and Medieval Studies, 2000), pp. 181-211 (p. 193); D. Hamilton, 'Andreas and Beowulf: placing the hero', in L. E. Nicholson and D. W. Frese (eds), Anglo-Saxon Poetry: Essays in Appreciation (Notre Dame, IN: University of Notre Dame Press, 1975), pp. 81-98 (p. 95); R. E. Bjork, The Old English Verse Saints' Lives: A Study in Direct Discourse and the Iconography of Style, McMaster Old English Studies and Texts, 4 (Toronto: University of Toronto Press, 1985), pp. 110-31 (pp. 121-4); D. G. Calder, 'Figurative language and its contexts in Andreas: a study in medieval expressionism', in P. R. Brown, G. R. Crampton and F. C. Robinson (eds), Modes of Interpretation in Old English 
Literature: Essays in Honor of Staney B. Greenfield (Toronto: University of Toronto Press, 1986), pp. 115-36 (p. 131); A. Harbus, 'A mind for hagiography: the psychology of resolution in Andreas', in K. E. Olsen, A. Harbus and T. Hofstra (eds), Germanic Texts and Latin Models: Medieval Reconstructions, Germania Latina, IV, Mediaevalia Groningana, 2 (Louvain: Peeters, 2001), pp. 127-40 (p. 132).

7 E. B. Irving, Jr., 'A reading of Andreas: the poem as poem', Anglo-Saxon England, 12 (1983), 215-37 (p. 229); H. Magennis, 'A funny thing happened on the way to heaven: humorous incongruity in Old English saints' lives', in J. Wilcox (ed.), Humour in Anglo-Saxon Literature (Cambridge: D. S. Brewer, 2000), pp. 137-57 (pp. 145-7); Herbison, 'Generic adaptation', 186-208: J. Wilcox, 'Eating people is wrong: funny style in Andreas and its analogues', in C. E. Karkov and G. H. Brown (eds), Anglo-Saxon Styles (Albany, NY: State University of New York Press, 2003), pp. 201-22 (pp. 207-9).

8 Herbison, 'Generic adaptation', pp. 185-7.

9 A. Orchard, 'The originality of Andreas', in L. Neidorf, R. J. Pascual and T. Shippey (eds), Old English Philology: Studies in Honour of R. D. Fulk (Cambridge: D. S. Brewer, 2016), pp. 331-52 8-9; A. M. Powell, 'Verbal parallels in Andreas and its relationship to Beowulf and Cynewulf' (unpublished $\mathrm{PhD}$ dissertation, University of Cambridge, 2002), pp. 168-232, esp. 175-6.

10 L. J. Peters, 'The relationship of the Old English Andreas to Beowulf', Proceedings of the Modern Language Association, 66.5 (1951), 844-63.

11 Hamilton, 'Placing the hero', pp. 82-94; A. R. Riedinger, 'The formulaic relationship between Beowulf and Andreas', in H. Damico and J. Leyerle (eds), Heroic Poetry in the Anglo-Saxon Period: Studies in Honor of Jess B. Bessinger, Jr., Studies in 
Medieval Culture, 32 (Kalamazoo, MI: Medieval Institute Publications, Western Michigan University, 1993), pp. 283-312 (p. 305).

12 J. Hill, 'The soldier of Christ in Old English prose and poetry', Leeds Studies in English, N.S., 12 (1981), 57-80.

13 R. North, The Origins of 'Beowulf': From Vergil to Wiglaf(Oxford: Oxford University Press, 2006), pp. 48-9.

14 All translations are my own.

15 M. D. J. Bintley, 'Demythologising urban landscapes in Andreas', Leeds Studies in English, N.S., 40 (2009), 105-18.

16 Wilcox, 'Eating people is wrong', pp. 208-9.

17 Bearbeitungen, ed. Blatt, p. 42; cf. Apocryphal New Testament, trans. MacDonald, p. 285. 18 Bearbeitungen, ed. Blatt, p. 43.

19 Wilcox, 'Eating people is wrong', p. 208.

20 Hamilton, 'Placing the hero', p. 83.

21 M. Lapidge, 'The archetype of Beowulf', Anglo-Saxon England, 29 (2000), 5-41 (37-8).

22 North, Origins of 'Beowulf', pp. 53, 108-9, 116.

23 Bearbeitungen, ed. Blatt, pp. 68-9.

24 Hamilton, 'Placing the hero', p. 86.

25 Wilcox, 'Eating people is wrong', pp. 210, 215-16.

26 Andreas, ed. Brooks, pp. 35 (text) and 99 (note).

27 Bearbeitungen, ed. Blatt, pp. 76-7.

$28 \mathrm{OE} \bar{u} ð w i t a$ (i.a.): for books, in The Battle of Brunanburh, line 69; as a gloss (uðuuta) for philosophus, in the Corpus Glossary, Anglo-Saxon and Old English Vocabularies, ed. T. Wright and R. P. Wülker, 2 vols (London: Trübner, 1884), I, 39 20; for experts on 
computus, in the Menologium, line 166; for Cato the Elder, in The Old English Boethius: An Edition of the Old English Versions of Boethius's De Consolatione Philosophiae, ed. M. Godden and S. Irvine, with M. Griffith and R. Jayatilaka, 2 vols (Oxford: Oxford University Press, 2009), I, 427 (C Text Metre 10. 48-51, esp. 50; cf. B Text, 19 24).

29 R. Boenig, 'Andreas, the Eucharist, and Vercelli', JEGP, 79 (1980), 313-31 (320). 30 Snorri Sturluson: Edda: Prologue and Gylfaginning, ed. A. Faulkes (Oxford: Oxford University Press, 1982), p. 48 (ch. 49); R. North, Heathen Gods in Old English Literature, CSASE, 22 (Cambridge: Cambridge University Press, 1997), 198-202. 31 North, Origins of 'Beowulf', pp. 199-202.

32 T. D. Hill, 'Figural narrative in Andreas: the conversion of the Mermedonians', Neuphilologische Mitteilungen, 70 (1969), 261-73: M. M. Walsh, 'The baptismal flood in the Old English Andreas: liturgical and typological depths', Traditio, 33 (1977), 137-58.

33 Calder, 'Figurative language and its contexts in Andreas', pp. 119-26; Hill, 'The soldier of Christ', pp. 71-2.

34 C. F. Brown, 'Poculum mortis in Old English', Speculum, 15 (1940), 389-99. G. V. Smithers, 'Five notes on Old English texts', English and Germanic Studies, 4 (195152), 65-85 (67-75); H. Magennis, 'The cup as symbol and metaphor in Old English literature', Speculum, 60 (1985), 517-36 (531-5).

35 Calder, 'Figurative language and its contexts in Andreas', p. 132.

36 J. Rowland, 'OE ealuscerwen/meoduscerwen and the concept of "paying for mead", Leeds Studies in English, N.S., 21 (1990), 1-12. 
37 Irving, 'A reading of Andreas', p. 235; see also his 'Wild party at Heorot', Tennessee Studies in Literature, 11 (1966), 161-8. J. Klegraf, 'Beowulf 769: ealuscer-wēn', Archiv für das Studium der neueren Sprachen und Literaturen, 208 (1971), 108-12; R. W. Hanning, 'Sharing, dividing, depriving: the verbal ironies of Grendel's last visit to Heorot', Tennessee Studies in Literature, 15 (1973), 203-12 (211).

38 W. Krause and H. Jankuhn, Die Runeneinschriften im älteren Futhark, Abhandlungen der Akademie der Wissenschaften in Göttingen, Philologisch-Historische Klasse (Göttingen: Vandenhoeck und Uprecht, 1966), pp. 239-41, 247-8, 255-9; P. Pieper, 'Die Runenstempel von Spong Hill: Pseudo-Runen oder Runenformel?', Neue Ausgräbungen und Forschungen in Niedersachsen, 17, 181-200 (181-6). On Old Scandinavian alu ('fortune') and skorin ('cut') on the Eggjum stone, see M. Olsen and A. Liestøl, Norges innskrifter med de yngre runer (Oslo: Kjeldeskriftfondet, 1924) I, pp. 225-32 (p. 227).

39 R. North, "Wyrd” and "wearð ealuscerwen" in Beowulf', Leeds Studies in English, N.S., 25 (1994), 69-82 (74-5).

40 The Poetic Edda: Volume II: Mythological Poems, ed. and trans. U. Dronke (Oxford: Oxford University Press, 1997), pp. 12 (text) and 128 (note).

41 Bearbeitungen, ed. Blatt, pp. 88-9.

42 Bearbeitungen, ed. Blatt, p. 145 (fol. 157 verso).

43 F. M. Biggs, 'The passion of Andreas: Andreas 1398-1491', Studies in Philology, 85 (1988), 413-27 (413).

44 See Andreas: An Edition, ed. R. North and M. Bintley (Liverpool: Liverpool University Press, 2016). 
